\title{
Correlation Coefficient Analysis for Yield and its Components in Rice (Oryza sativa L.) Genotypes
}

\author{
B. Kalyan ${ }^{1 *}$, K.V. Radha Krishna ${ }^{1}$ and L.V. Subba Rao ${ }^{2}$ \\ ${ }^{1}$ Department of Genetics and Plant Breeding, College of Agriculture, Rajendranagar, PJTSAU, \\ Hyderabad-500030, Telangana, India \\ ${ }^{3}$ Crop Improvement Section, Indian Institute of Rice Research, Rajendranagar, \\ Hyderabad-500030, Telangana, India \\ *Corresponding author
}

\begin{tabular}{|c|c|}
\hline & A B S T R A C T \\
\hline Keywords & \multirow{5}{*}{$\begin{array}{l}\text { Seventy genotypes of rice (Oryza sativa L.) were evaluated during Kharif } 2014 \text { to } \\
\text { study the nature and extent of correlation among yield and yield attributing } \\
\text { characters, number of tillers per plant, number of effective tillers per plant, plant } \\
\text { height, panicle length, number of filled grains per panicle, } 1000 \text {-grain weight, days } \\
\text { to } 50 \text { per cent flowering, days to maturity, grain yield per plant. Character } \\
\text { association studies revealed that the characters grain yield per plant showed } \\
\text { significant positive association with plant height, number of tillers per plant, } \\
\text { number of productive tillers per plant, number of filled grains per panicle and } \\
1000 \text { grain weight. This indicated that simultaneous selection of all these } \\
\text { characters was important for yield improvement. }\end{array}$} \\
\hline Rice, Yield, & \\
\hline $\begin{array}{l}\text { Yield components, } \\
\text { Correlation. }\end{array}$ & \\
\hline Article Info & \\
\hline $\begin{array}{l}\text { Accepted: } \\
\text { 23 June } 2017 \\
\text { Available Online: } \\
\text { 10 July } 2017\end{array}$ & \\
\hline
\end{tabular}

\section{Introduction}

To break the yield barriers in rice breeding strategies, attempts are being made. Crop yield is the end product of the interaction of a number of other interrelated attributes. A thorough understanding of the interaction of characters among themselves had been of great use in plant breeding. The efficiency of selection for yield mainly depends on the direction and magnitude of association between yield and its component characters and also among themselves. Character association provides information on the nature and extent of association between pairs of metric traits and helps in selection for the improvement of the character.
For the improvement of grain yield, the knowledge on the association between grain yield and its component characters will be helpful.

The present study was, therefore, undertaken to understand the association among grain yield and its component characters. Phenotypic and genotypic correlations were worked out on yield and yield contributing characters in 70 genotypes. In general, genotypic correlations were found to be higher than phenotypic correlations, which indicate that though there is strong inherent association between characters studies, its 
expression is lessened due to influence of environment and considering the importance of phenotypic correlation

\section{Materials and Methods}

The present study comprised of 70 genetically diverse genotypes of rice (Oryza sativa L.) procured from different sources. The experiment was carried out at IIRR farm, ICRISAT campus, Patancheru, Hyderabad during kharif 2014. The experimental trial was laid out in Randomized Complete Block design with three replications under irrigated conditions. Each plot comprised of two 6 rows of 6 meter length spaced $30 \mathrm{~cm}$ apart with plant to plant spacing of $20 \mathrm{~cm}$. Data on the basis of 5 randomly taken competitive plants excluding borders were recorded on grain yield per plant $(\mathrm{g})$, plant height $(\mathrm{cm})$, total number of tillers, number of effective tillers per plant, panicle length $(\mathrm{cm})$, number of filled grains per panicle, 1000-grain weight (g) were recorded as individual plant basis while days to 50 per cent flowering and days to maturity were recorded on plot basis. The analysis was done as per Panse and Sukhatme (1985).

\section{Results and Discussion}

The days to 50 per cent flowering recorded a non-significant negative phenotypic correlation with grain yield per plant ($0.1170)$, plant height $(-0.0685)$, number of filled grains per panicle (-0.0112), 1000 grain weight $(-0.0871)$ and positive and significant correlation with panicle length (0.2103), Days to maturity $(0.8365)$. The characters, number of tillers per plant (-0.1360), number of productive tillers per plant $(-0.1408)$ showed negative and significant correlation association. The similar results were reported by Meenakshi et al., (1999), Nagaraju et al., (2013) for grain yield per plant. Nandhan et al., (2010) for 1000 grain weight, plant height and Days to maturity, Meenakshi et al., (1999) for number of filled grains per panicle, Ravindra Babu et al., (2012) for number of productive tillers per plant.

The plant height registered a significant positive phenotypic correlation with grain yield per plant (0.4117), number of tillers per plant (0.2973), panicle length (0.2708), number of productive tillers per plant (0.2749) and number of filled grains per panicle $(0.4364)$ where as it is negative and significant correlation with days to maturity (0.2146) and it had negative non-significant correlation with 1000 grain weight (g) (0.0573). The present results are in agreement with the results reported by Satish Chandra et al., (2009), Rahman et al., (2014) for number of productive tillers per plant, Satish Chandra et al., (2009), Ravindra Babu et al., (2012), Reddy et al., (2013), Rao et al., (2014) for panicle length, number of filled grains per panicle and 1000 grain weight, Mohanty et al., (2012), Reddy et al., (2013), Patel et al., (2014) for grain yield per plant. Meenakshi et $a l$. , (1999) for 1000 grain weight (g), days to maturity.

Number of tillers per plant exhibited significant positive phenotypic correlation with grain yield per plant (0.6214) and number of productive tillers per plant (0.9738). The character number of filled grains per panicle (-0.1930), panicle length ($0.2340)$, days to maturity $(-0.2373), 1000$ grain weight $(-0.0619)$ showed negative nonsignificant correlation. Idris et al., (2013) reported similar results for grain yield per plant.

Number of productive tillers per plant exhibited significant positive phenotypic correlation with grain yield per plant $(0.6215)$ and number of filled grains per panicle (0.1655). It had significant negative correlation with panicle length (-0.2201), 
1000 grain weight $(-0.2305)$. The character days to maturity showed negative and nonsignificant correlation (-0.0248). The earlier results reported by Satish Chandra et al., (2009), Ravindra Babu et al., (2012), Nagaraju et al., (2013), Patel et al., (2014) for grain yield per plant Ravindra Babu et al., (2012), Rahman et al., (2014) for panicle length Padmaja et al.,(2011), Rahman et al., (2014) for 1000 grain weight and Reddy et al., (2013), for days to maturity were in agreement to the present results.

Panicle length registered significant negative phenotypic correlation with grain yield per plant (-0.2091) and positive significant correlation with days to maturity $(0.1755)$. It had negative non-significant correlation with number of filled grains per panicle $(-0.0499)$ and 1000 grain weight $(-0.1294)$. The similar results were reported by Rao et al., (2014) for number of filled grains per panicle, Vange et $a l$. , (1999) for 1000 grain weight, Basavaraj et $a l .,(2011)$ for grain yield per plant.

Number of filled grains per panicle exhibited a significant positive phenotypic correlation with grain yield per plant (0.6056) where as negative and significant correlation with 1000 grain weight $(-0.0707)$ and negative and nonsignificant correlation with days to maturity (0.0913). Nayak et al., (2001) for 1000 grain weight, Reddy et al., (2013), Patel et al., (2014) for grain yield per plant and for days to maturity reported similar results.

1000 grain weight showed a significant positive phenotypic correlation with grain yield per plant (0.4011). Similar results were reported by Satish Chandra et al., (2009), Basavaraja et al., (2011), Patel et al., (2014), Rao et al., (2014) for grain yield per plant. Days to maturity showed significant negative phenotypic correlations with grain yield per plant (-0.1937) and 1000 grain weight had negative and non-significantly correlated ($0.0253)$. The results were reported by Nandan et al., (2010) for grain yield per plant were in coincidence to the present results.

Phenotypic correlations revealed that grain yield per plant had significant positive association with Plant height (0.4117), number of tillers per plant (0.6214), number of productive tillers per plant (0.6215), number of filled grains per panicle (0.6056), 1000 grain weight (0.4011). The trait recorded a significant negative association with days to maturity (-0.1937), panicle length (-0.2091) and the character days to fifty per cent flowering showed negative nonsignificant with grain yield per plant (Table $1)$.

Grain yield per plant showed positive significant association with plant height, number of tillers per plant, number of productive tillers per plant, number of filled grains per panicle.

This indicated that all these characters were important for yield improvement. Similar kind of association was revealed by Mohanty et al., (2012), Reddy et al., (2013), Patel et al., (2014) for plant height, Ravindra Babu et al.,(2012), Nagaraju et al., (2013), Patel et al., (2014) and Rao et al., (2014) number of productive tillers per plant, Padmaja et al., (2011), Reddy et al., (2013) and Patel et al., (2014) for number of filled grains per panicle. Hence, these characters could be considered as criteria for selection for higher yield as these were mutually and directly associated with grain yield.

The character 1000 grain weight also positively associated with grain yield per plant it indicates that these characters can be considered for selection for higher yield. 
Table.1 Phenotypic (P) correlation coefficient analysis of yield and yield contributing characters in rice

\begin{tabular}{|c|c|c|c|c|c|c|c|c|c|}
\hline Character & $\begin{array}{c}\text { Days to } \\
50 \% \\
\text { Flowering }\end{array}$ & $\begin{array}{c}\text { Plant } \\
\text { height } \\
(\mathrm{cm})\end{array}$ & $\begin{array}{l}\text { No. of } \\
\text { tillers/ } \\
\text { plant }\end{array}$ & $\begin{array}{l}\text { No of } \\
\text { prod. } \\
\text { tillers / } \\
\text { Plant }\end{array}$ & $\begin{array}{l}\text { Panicle } \\
\text { length } \\
(\mathrm{cm})\end{array}$ & $\begin{array}{l}\text { No. of } \\
\text { filled } \\
\text { grains/ } \\
\text { panicle }\end{array}$ & $\begin{array}{l}\text { Days to } \\
\text { maturity }\end{array}$ & $\begin{array}{c}1000 \\
\text { Grain } \\
\text { weight } \\
\text { (g) }\end{array}$ & $\begin{array}{c}\text { Grain } \\
\text { yield/ } \\
\text { Plant (g) }\end{array}$ \\
\hline Days to $50 \%$ & 1.0000 & -0.0685 & $-0.1360 *$ & $-0.1408 *$ & $0.2103 * *$ & -0.0112 & $0.8365 * *$ & -0.0871 & -0.1170 \\
\hline $\begin{array}{l}\text { Plant height } \\
\text { (cm) }\end{array}$ & & 1.0000 & $0.2973 * *$ & $0.2749 * *$ & $0.2708 * *$ & $0.4364 * *$ & $-0.2146 * *$ & -0.0573 & $0.4117 * *$ \\
\hline $\begin{array}{l}\text { Number of } \\
\text { tillers / plant }\end{array}$ & & & 1.0000 & $0.9738 * *$ & $-0.2340 * *$ & $-0.1930 * *$ & $-0.2373 * *$ & $-0.0619 *$ & $0.6214 * *$ \\
\hline $\begin{array}{l}\text { Number of } \\
\text { prod. tillers / } \\
\text { plant }\end{array}$ & & & & 1.0000 & $-0.2201 * *$ & $0.1655^{*}$ & -0.0248 & $-0.2305 * *$ & $0.6215 * *$ \\
\hline $\begin{array}{l}\text { Panicle Length } \\
\text { (cm) }\end{array}$ & & & & & 1.0000 & -0.0499 & $0.1755^{*}$ & -0.1294 & $-0.2091 * *$ \\
\hline $\begin{array}{l}\text { Number of } \\
\text { filled } \\
\text { grains/panicle }\end{array}$ & & & & & & 1.0000 & -0.0913 & $-0.0707 * *$ & $0.6056 * *$ \\
\hline $\begin{array}{l}\text { Days to } \\
\text { maturity }\end{array}$ & & & & & & & 1.0000 & -0.0253 & $-0.1937 * *$ \\
\hline $\begin{array}{l}1000 \text { Grain } \\
\text { weight (g) }\end{array}$ & & & & & & & & 1.0000 & $0.4011 * *$ \\
\hline
\end{tabular}


In conclusion, character association studies revealed that the characters grain yield per plant showed significant positive association with plant height, number of tillers per plant, number of productive tillers per plant, number of filled grains per panicle and 1000 grain weight. This indicated that simultaneous selection of all these characters was important for yield improvement.

A critical analysis of correlation indicated that emphasis should be directed towards selection of parents having higher number of productive tillers per plant coupled with higher number of filled grains per panicle, 1000 grain weight, plant height and panicle length also. As the yield component, filled grains per panicle are intern dependent on panicle length and plant height, attention should be paid towards increasing the panicle length, maintaining optimum plant height. Thus, a plant with medium height, sturdy culm with increased panicle length, higher number of filled grains per panicle and productive tillers per plant would be more desirable for selection to realize higher yield.

\section{References}

Basavaraja, T., Gangaprasad, S., Dhusyantha Kumar, B. M and Shilaja Hittlamani. 2011. Correlation and path analysis of yield and yield attributes in local rice cultivars (Oryza sativa L.). Electronic J. Plant Breeding, 2(4): 523-526.

Idris, A.E. and Mohammed, K.A. 2013. estimation of genetic variability and correlation for grain yield components in rice(Oryza sativa L.) Global J. Plant Ecophysiol., 3(1): 1-6.

Madhavilatha, L., Sekhar, M. R., Suneetha, Y and Srinivas, T. 2005. Genetic variability, correlation and path analysis for yield and quality traits in rice (Oryza sativa L.) Res. Crops., 6(3): 527-537.

Meenakshi, T., Amirthadevarathinam, A. and
Backiyarani, S. 1999. Correlation and path analysis of yield and some physiological characters in rainfed rice. Oryza. 36(2): 154-156.

Mohanty, N.M., Sekhar, R., Reddy, D.M and Sudhakar, P. 2012. Genetic variability and character association of agromorphological and quality characters in rice. Oryza, 49(2): 88-92.

Nagaraju, C., Sekhar, M.R., Reddy, K.H and Sudhakar, P. 2013. Correlation between traits and path analysis coefficient for grain yield and other components in rice (Oryza sativa L.) genotypes. Int. J. Appl. Biol. Pharmaceutical Technol., 4(3): 137-142.

Nandan, R., Sweta and Singh, S.K. 2010. Character Association and Path Analysis in Rice (Oryza sativa L.) Genotypes. World J. Agri. Sci., 6(2): 201-206.

Nayak, A.R., Chaudhary, D and Reddy, J.N. 2001. Correlation and path analysis in scented rice (Oryza sativa L). Indian J. Agri. Res., 35(3): 186-189.

Padmaja, D., Radhika, K., Subba Rao, L.V and Padma, V. 2011. Correlation and path analysis in rice germplasm. Oryza, 48(1): 69-72.

Panse, V.G. and Sukhatme, P.V. 1978. Statistical methods for Agricultural Workers. ICAR, New Delhi. 235-246.

Patel, J.R., Saiyad, M.R., Prajapati, K.N., Patel, R.A and Bhavani R.T. 2014. Genetic variability and character association studies in rainfed upland rice (Oryza sativa $\quad$ L.) Electronic J. Plant Breeding, 5(3): 531-537.

Rahman, M.A., Hossain, M.S., Chowdhury, I.F., Matin, M.A and Mehraj, H. 2014. Variability study of advanced fine rice with correlation, path co-efficient analysis of yield and yield contributing characters. Int. J. Appl. Sci. Biotechnol., Vol 2(3): 364-370. 
Rao, V.T., Mohan, Y.C., Bhadru, D., Bharathi, D and Venkanna, V. 2014. Genetic variability and association analysis in rice. Int. J. Appl. Biol. Pharmaceutical Technol., vol. 5, issue 2.

Ravindra Babu, V., Shreya, K., Kuldeep Singh Dangi, Usharani, G., Siva Shankar, A. 2012. Correlation and Path Analysis Studies in Popular Rice Hybrids of India. Int. J. Scientific and Res. Publications, 2(3): 156-158.

Reddy, G.E., Suresh, B.G., Sravan, T and Reddy, P.A. 2013.Interrelationship and cause-effect analysis of rice genotypes in North East plain zone. The Bioscan, 8(4): 1141-1144.

Satish Chandra, B., Dayakar Reddy, T., Ansari, N.A. and Sudheer Kumar, S. 2009. Correlation and path analysis for yield and yield components in rice (Oryza sativa L.) Agri. Sci. Digest, 29(1): 45-47.

Vange, T., OJo, A.A. and Bellow, L.L. 1999. Genetic variability, stability and correlation studies in lowland rice (Oryza sativa L.) genotypes. Indian J. Agri. Sci., 69(1): 30-3.

\section{How to cite this article:}

Kalyan, B., K.V. Radha Krishna and Subba Rao, L.V. 2017. Correlation Coefficient Analysis for Yield and its Components in Rice (Oryza sativa L.) Genotypes. Int.J.Curr.Microbiol.App.Sci. 6(7): 2425-2430. doi: https://doi.org/10.20546/ijcmas.2017.607.287 